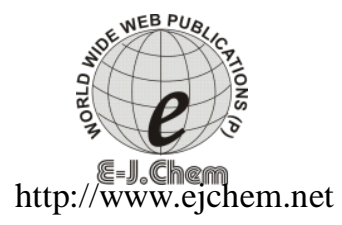

ISSN: 0973-4945; CODEN ECJHAO

E-Journal of Chemistry

2012, 9(4), 2119-2127

\title{
Synthesis, Physical Characterization of M(III) Transition Metal Complexes Derived from Thiodihydrazide and 5-tert-Butyl-2-hydroxy-3-(3- phenylpent-3-yl) Benzaldehyde
}

\author{
GAJENDRA KUMAR $^{\mathrm{a}}$, RAJEEV JOHARI ${ }^{\mathrm{b}}$, AND SHOMA DEVI ${ }^{\mathrm{c}}$ \\ ${ }^{a}$ Chemical Science Laboratory, BIT Muzaffarnagar 251315, Uttar Pradesh, India \\ ${ }^{b}$ Department of Chemistry, Vardhaman College, Bijnor 246701, Uttar Pradesh, India \\ ${ }^{c}$ Department of Zoology, Vardhaman College, Bijnor 246701, Uttar Pradesh, India \\ gaj.chem@gmail.com
}

Received 22 September 2011; Accepted 13 November 2011

\begin{abstract}
A Schiff base ligand was synthesized by reacting 5-tert-butl-2hydroxy-3-(3-phenylpent-3-yl) benzaldehyde and thiodihydrazide (2:1) and a series of metal complexes with this new ligand were synthesized by reaction with $\mathrm{Cr}$ (III), Mn (III), and Fe (III) metal salt in methanolic medium. The Schiff base ligand and its complexes have been characterized with the help of elemental analysis, conductance measurements, magnetic measurements and their structure configuration have been determined by various spectroscopic (electronic, IR, ${ }^{1} \mathrm{H}$ NMR, ${ }^{13} \mathrm{C}$ NMR, GCMS) techniques. Electronic and magnetic moments of the complexes indicate that the geometries of the metal centers were octahedral. IR spectral data suggest that ligand behaves as a tetradentate ligand with ONNO donor sequence towards the metal ion.
\end{abstract}

Keywords: Schiff base, Metal complexes, Spectral characterization.

\section{Introduction}

The role play by metals in a number of biological systems has derived the research efforts of many scientists from a variety of field [1-3]. There are a number of important molecules shows biological activities including antibacterial, antifungal [4-13], antidiabetic [14], antitumor [15-17], antproliferative [18,19], anticancer [20,21], herbicidal [22], anticorrosion and anti-inflammatory activities [5-7]. Schiff bases represent an important class of compounds because they are utilized as starting materials in the synthesis of industrial products [23]. Moreover, Schiff base are regarded as privileged ligand [24]. Due to their capability to form complexes with different transition metals can act as catalysts for many different reactions [25-29]. The cross linking agents can also be derived from metal complexes with $\mathrm{O}-\mathrm{N}-$ or $-\mathrm{S}$ ligands for example, the intra-coordination salt such as salicylates, anthraanilates and aliphatic or aromatic amines can form strong five of six membered chelates rings which are able to produce the metal containing cross linking agents 
with required properties [30]. It is well known that $\mathrm{N}$ and $\mathrm{S}$ atoms play a key role in the coordination of metals at the active sites of numerous metallobiomolecules [31]. Metallorganic chemistry is becoming an emerging area of research due to the demand of new metalbased antibacterial and antifingal compounds [32,33]. In this study the synthesis of metal complexes with Schiff base derived from 5-tert-butyl-2-hydroxy-3-(3-phenylpent-3yl) benzaldehyde and thiodihydrazide. There Schiff base have donor sites with the ONNO sequence and varied coordination abilities.

\section{Experimental}

\section{Reagents}

The entire chemicals used were of the analytical reagent grade thiodihydrazide, p-tertbutylphenol and 3-phenylpent-2-ene procured from fluka, DMSO, $\mathrm{CH}_{2} \mathrm{Cl}_{2}$, methanol and ethanol were procured from s.d.-fine. Metal salts were purchased from Merck.

\section{Synthesis of 5-tert-Butyl-2-hydroxy-3-(3-phenylpent-3-yl) benzaldehyde}

To stirred solution of p-tert-butylphenol and 3-phenylpent-2-ene in of $\mathrm{CH}_{2} \mathrm{Cl}_{2}$ was added sulfuric acid drop wise at $0{ }^{\circ} \mathrm{C}$. The resulting solution was stirred overnight at room temperature. Then water and $\mathrm{CH}_{2} \mathrm{Cl}_{2}$ were added, and the organic phase was separated, washed with saturated $\mathrm{NaHCO}_{3}$, dried with $\mathrm{MgSO}_{4}$, and concentrated. The resulting crude reaction mixture was dissolved in a minimum volume of hot $\mathrm{EtOH}$ and crystallized. The recrystallized product reacts with polymeric formaldehyde in the presence of $\mathrm{SnCl}_{4}$ to form 5-tert-Butyl-2-hydroxy-3-(3-phenylpent-3-yl) benzaldehyde [34].

\section{Synthesis of the ligand}

The ligand was prepared by the condensation of 5-tert-Butyl-2-hydroxy-3-(3-phenylpent-3yl) benzaldehyde with thiodihydrazide (2:1). A mixture of ethanol/dichloromethane (1:3) was used as a solvent in the presence of anhydrous magnesium sulphate as a dehydrating agent $[35,36]$ (scheme 1).<smiles>C/C=C(\CC)c1ccccc1</smiles> 


\section{Synthesis of the metal complexes}

The metal complexes of the ligand HL (1) were prepared by mixing a hot methanolic solution of the metal salts with required amount of a hot ethanolic solution of the ligand to form metal/ligand complexes (Scheme 2).

\section{Physical measurements}

The microanalysis of C, $\mathrm{H}$ and $\mathrm{N}$ were estimated by elemental analyzer (Perkin Elmer 2400 (table 1) and the metal contents of Cr (III), Mn (III) and Fe (III) were determined by atomic absorption spectrophotometer (Perkin Elmer 5000). IR spectra were recorded on a FT-IR spectrophotometer (Perkin Elmer) in the range 4000-200 $\mathrm{cm}^{-1}$ using Nujol Mull. ${ }^{1} \mathrm{H}$ NMR and ${ }^{13} \mathrm{C}$ NMR spectra (at room temperature) (in DMSO- $\mathrm{d}_{6}$ ) were recorded on a Bruker AVANCE II $300 \mathrm{DRX}$ or average $400 \mathrm{DRX}$ spectrometer with reference to $\mathrm{Me}_{4} \mathrm{Si}(0.0$ ppm).

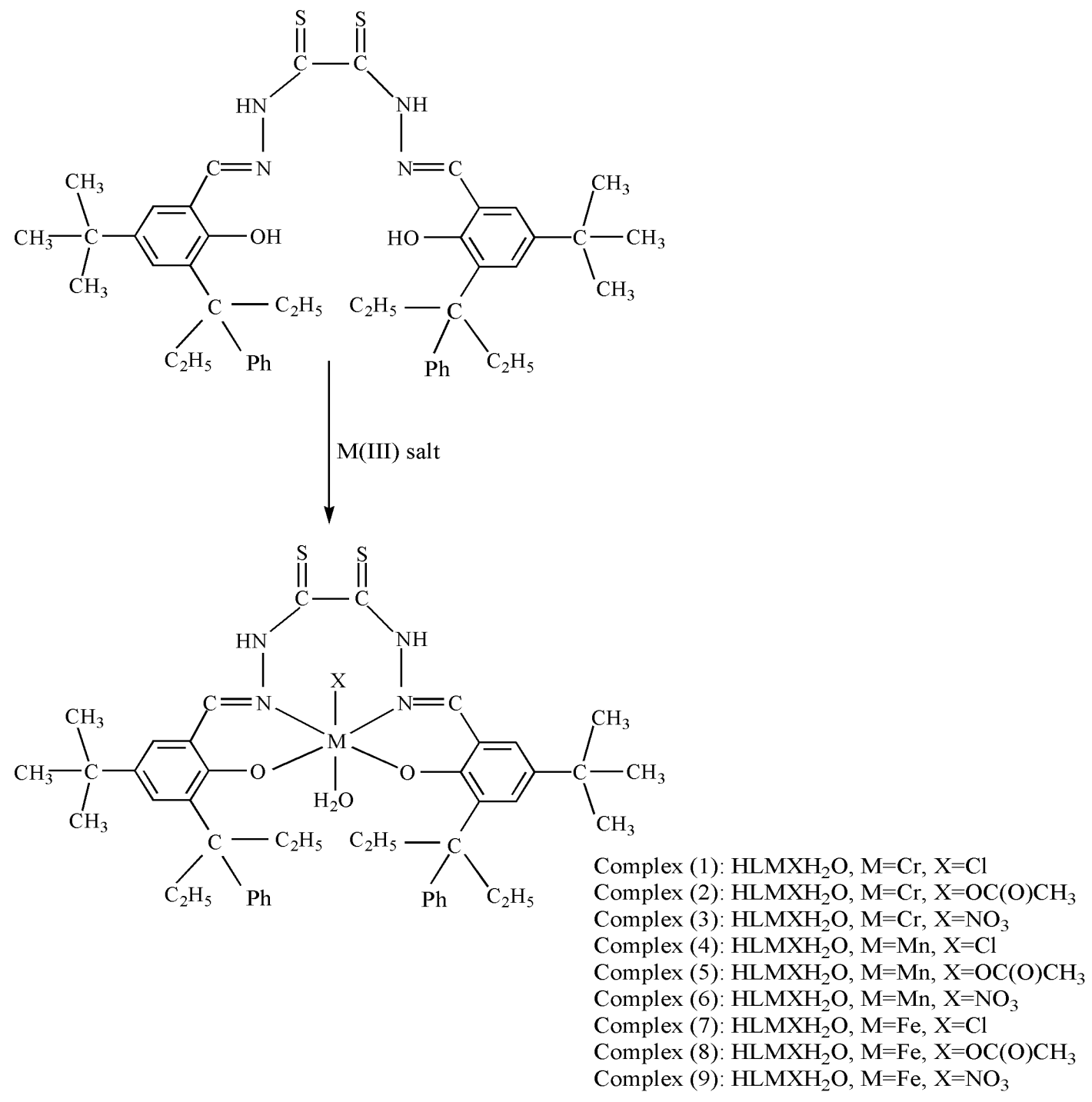

Scheme 2. Formation of Schiff base metal complex 
The FAB mass spectra (at room temperature) were recorded on JEUL JMS-AX-500 mass spectrometer, GC-MS analysis was performed on a Shimadzu GCMS- QP5050A instrument, Indian Institute of Petroleum Dehradun, India. Magnetic susceptibility measurements were carried out at SAIF, IIT Roorkee, on vibrating sample magnetometer (Model PAR 155). Electronic spectra in DMSO were recorded on a Hitachi 330 spectrophotometer (1300-200 $\mathrm{nm})$ at room temperature. The conductivity was measured on digital conductivity meter (HPG system, G-3001).

Table 1. Elemental analysis in \%, molar conductance $\left(\Lambda_{M}\right.$ in DMSO) of the Schiff base ligand and its metal complexes.

\begin{tabular}{|c|c|c|c|c|c|c|}
\hline Compounds & FW & $\mathrm{C}$ & $\mathrm{H}$ & $\mathrm{N}$ & $\mathrm{M}$ & $\Lambda_{\mathrm{M}}$ \\
\hline Ligand & 762.97 & $72.40(72.40)$ & $7.66(7.64)$ & 7.34(7.32) & & \\
\hline $\mathrm{HLCrClH}_{2} \mathrm{O}$ & 865.30 & $63.76(63.58)$ & $6.75(6.88)$ & $6.47(6.48)$ & $6.00(5.92)$ & $69 \Omega^{-1}$ \\
\hline $\mathrm{HLCrNO}_{3} \mathrm{H}_{2} \mathrm{O}$ & 892.32 & $61.86(61.68)$ & $6.55(6.78)$ & 7.84(7.18) & $5.82(5.79)$ & $65 \Omega^{-1}$ \\
\hline $\mathrm{HLCrOAcH}_{2} \mathrm{O}$ & 889.34 & $64.77(64.60)$ & $6.91(6.92)$ & $6.29(6.25)$ & $5.84(5.80)$ & $56 \Omega^{-1}$ \\
\hline $\mathrm{HLMnClH}_{2} \mathrm{O}$ & 868.30 & $63.54(63.35)$ & $6.72(6.92)$ & $6.44(6.38)$ & $6.32(6.42)$ & $19 \Omega^{-1}$ \\
\hline $\mathrm{HLMnNO}_{3} \mathrm{H}_{2} \mathrm{O}$ & 895.32 & $61.66(61.58)$ & $6.52(6.42)$ & $7.82(7.74)$ & $6.13(6.12)$ & $65 \Omega^{-1}$ \\
\hline $\mathrm{HLMnOAcH}_{2} \mathrm{O}$ & 892.34 & $64.55(64.42)$ & $6.88(6.89)$ & $6.27(6.04)$ & $6.15(6.12)$ & $56 \Omega^{-1}$ \\
\hline $\mathrm{HLFeClH}_{2} \mathrm{O}$ & 869.29 & $63.48(63.37)$ & $6.72(6.62)$ & $6.44(6.50)$ & $6.42(6.43)$ & $17 \Omega^{-1}$ \\
\hline $\mathrm{HLFeNO}_{3} \mathrm{H}_{2} \mathrm{O}$ & 896.31 & $61.60(62.48)$ & $6.52(6.68)$ & $7.81(7.78)$ & $6.23(6.22)$ & $65 \Omega^{-1}$ \\
\hline $\mathrm{HLFeOAcH}_{2} \mathrm{O}$ & 893.34 & $64.49(64.25)$ & $6.88(7.01)$ & $6.27(6.19)$ & $6.25(6.22)$ & $15 \Omega^{-1}$ \\
\hline
\end{tabular}

Synthesis of the Schiff base ligand

A round-bottom, $100 \mathrm{~mL}$ flask was charged with thiodihydrazide $\left(0.295 \mathrm{~g}, 2.5 \mathrm{mmol}, \mathrm{K}_{2} \mathrm{CO}_{3}\right.$ $(1.2 \mathrm{~g}, 5 \mathrm{mmol})$, and water $(6 \mathrm{~mL})$. The resulted mixture was stirred for $10 \mathrm{~min}$ followed by addition of ethanol $(98 \%, 30 \mathrm{~mL})$ and heated to $60-70{ }^{\circ} \mathrm{C}$ for $0.5 \mathrm{~h}$. The temperature was maintained, and 5-tert-Butyl-2-hydroxy-3-(3-phenylpent-3-yl)benzaldehyde (1.62 g, 5 mmol) was added. The mixture was refluxed for $3 \mathrm{~h}$. The mixture was concentrated to $1 / 4$ of its initial volume, dissolved in $\mathrm{CH}_{2} \mathrm{Cl}_{2}(50 \mathrm{~mL})$, and washed with water. The organic phase was dried and concentrated to give a yellow solid which was dissolved in $15 \mathrm{~mL}$ of hot ethanol. The resulting solution was cooled to ambient temperature, and $3 \mathrm{~mL}$ of $50 \%$ aqueous ethanol was added to produce yellow precipitate that was collected with $81 \%$ yield: yellow crystals. UV/vis (Nujol mul (nm)): $\lambda=280,330,340$. UV/vis $\left(1 \times 10^{-4} \mathrm{~mol}, \mathrm{DMSO}\right)$ : $\lambda=270,290,345$. IR $(\mathrm{KBr}): v\left(\mathrm{~N}^{2} \mathrm{H}\right) 3240(\mathrm{br}), v(\mathrm{C}=\mathrm{S}) 780(\mathrm{~s}), v(\mathrm{C}=\mathrm{N}) 1678(\mathrm{~s}), v(\mathrm{~N}-\mathrm{N})$ $1122(\mathrm{~s}) \mathrm{cm}^{-1} .{ }^{1} \mathrm{H}$ NMR $\left(500 \mathrm{MHz}, \mathrm{CDCl}_{3}\right) \delta 13.10(\mathrm{~s}, 2 \mathrm{H}), 7.98(\mathrm{~s}, 2 \mathrm{H}), 7.43(\mathrm{~d}, J=2.4$ $\mathrm{Hz}, 2 \mathrm{H}), 7.08-7.20(\mathrm{~m}, 10 \mathrm{H}), 6.89(\mathrm{~d}, J=2.4 \mathrm{~Hz}, 2 \mathrm{H}), 1.98-2.07(\mathrm{~m}, 4 \mathrm{H}), 1.70-1.80(\mathrm{~m}$, $4 \mathrm{H}), 1.49-1.59(\mathrm{~m}, 2 \mathrm{H}), 1.28(\mathrm{~s}, 18 \mathrm{H}), 0.57(\mathrm{t}, J=7.3 \mathrm{~Hz}, 6 \mathrm{H}), 0.51(\mathrm{t}, J=7.3 \mathrm{~Hz}, 6 \mathrm{H}) ;{ }^{13} \mathrm{C}$ NMR $\left(125 \mathrm{MHz}, \mathrm{CDCl}_{3}\right) \delta 159.7,148.6,139.2,133.2,129.2,127.2,127.0,125.9,124.7$, 
117.6, 72.3, 49.0, 34.0, 32.9, 31.4, 28.1, 27.2, 4.2. Elemental analysis for $\mathrm{C}_{46} \mathrm{H}_{58} \mathrm{~N}_{4} \mathrm{O}_{2} \mathrm{~S}_{2}$ (762.97): calcd. C 72.41, H 7.66, N 7.34; found C 72.40, H 7.64, N 7.32.

Synthesis of the metal complex (1)

Synthesis of $\mathrm{HLCrClH}_{2} \mathrm{O}$ complex (1). A solution of $\mathrm{CrCl}_{3} \cdot 6 \mathrm{H}_{2} \mathrm{O}(0.446 \mathrm{~g}, 1.678 \mathrm{mmol})$ in methanol $(8 \mathrm{~mL})$ was added to a hot solution $\left(75^{\circ} \mathrm{C}\right)$ of $\mathrm{HL}(1)(1.226 \mathrm{~g}, 1.678 \mathrm{mmol})$ in ethanol $(25 \mathrm{~mL})$, and the reaction mixture was refluxed for $2.5 \mathrm{~h}$. The solution was concentrated under vacuum. The precipitate was filtered off, washed with methanol and dried under vacuum over anhydrous $\mathrm{CaCl}_{2}\left(1.06 \mathrm{~g}, 71 \%\right.$ yield). Conductance $4 \mathrm{~m}: 69 \Omega^{-1} \mathrm{~cm}^{2}$ $\mathrm{mol}^{-1}$. UV/vis (Nujol mul (nm)): $\lambda=255,275,320,525,720$ and 1155. IR $(\mathrm{KBr}): v\left(\mathrm{H}_{2} \mathrm{O}\right)$ $3429(\mathrm{br}), v\left(\mathrm{~N}^{2} \mathrm{H}\right) 3272(\mathrm{br}), v(\mathrm{C}=\mathrm{S}) 790(\mathrm{w}), v(\mathrm{C}=\mathrm{N}) 1644(\mathrm{~m}), v(\mathrm{~N}-\mathrm{N}) 1122(\mathrm{w}), v(\mathrm{M}-\mathrm{N})$ $425, v(\mathrm{M}-\mathrm{O}) 490 \mathrm{~cm}^{-1}$. Elemental analysis for $\mathrm{C}_{46} \mathrm{H}_{58} \mathrm{ClCrN}_{4} \mathrm{O}_{3} \mathrm{~S}_{2}$ (865.30): calcd. $\mathrm{C} 63.76$, H 6.75, N 6.47, Cr 6.00; found C 63.58, H 6.88, N 6.48, Cr 5.92.

Synthesis of the metal complex (2)

Synthesis of $\mathrm{HLCrNO}_{3} \mathrm{H}_{2} \mathrm{O}$ complex (2). A solution of $\mathrm{CrNO}_{3} \cdot 6 \mathrm{H}_{2} \mathrm{O}(0.346 \mathrm{~g}, 1.562 \mathrm{mmol})$ in methanol $(8 \mathrm{~mL})$ was added to a hot solution $\left(75^{\circ} \mathrm{C}\right)$ of $\mathrm{HL}(1)(1.127 \mathrm{~g}, 1.478 \mathrm{mmol})$ in ethanol $(25 \mathrm{~mL})$, and the reaction mixture was refluxed for $2.5 \mathrm{~h}$. The solution was concentrated under vacuum. The precipitate was filtered off, washed with methanol and dried under vacuum over anhydrous $\mathrm{CaCl}_{2}(1.16 \mathrm{~g}, 75 \%$ yield $)$. Conductance $\Lambda \mathrm{m}: 65 \Omega^{-1}$ $\mathrm{cm}^{2} \mathrm{~mol}^{-1}$. UV/vis (Nujol mul (nm)): $\lambda=255,275,320,525,720$ and 1155. IR $(\mathrm{KBr}): v\left(\mathrm{H}_{2} \mathrm{O}\right)$ $3429(\mathrm{br}), v\left(\mathrm{~N}^{2} \mathrm{H}\right) 3272(\mathrm{br}), v(\mathrm{C}=\mathrm{S}) 780(\mathrm{w}), v(\mathrm{C}=\mathrm{N}) 1644(\mathrm{~m}), v(\mathrm{~N}-\mathrm{N}) 1120(\mathrm{w}), v(\mathrm{M}-\mathrm{N})$ $422, v(\mathrm{M}-\mathrm{O}) 485 \mathrm{~cm}^{-1}$. Elemental analysis for $\mathrm{C}_{46} \mathrm{H}_{58} \mathrm{CrN}_{5} \mathrm{O}_{6} \mathrm{~S}_{2}$ (892.32): calcd. C 61.86, $\mathrm{H}$ 6.55, N 7.84, Cr 5.82; found C 61.68, H 6.78, N 7.81, Cr 5.79.

Synthesis of the metal complex (3)

Synthesis of $\mathrm{HLCrOAcH}_{2} \mathrm{O}$ complex (3). A solution of $\mathrm{Cr}(\mathrm{OAc})_{3} \cdot 4 \mathrm{H}_{2} \mathrm{O}(0.536 \mathrm{~g}, 1.781$ $\mathrm{mmol})$ in methanol $(7 \mathrm{~mL})$ was added to a hot solution $\left(75^{\circ} \mathrm{C}\right)$ of $\mathrm{HL}(1)(1.301 \mathrm{~g}, 1.781$ $\mathrm{mmol})$ in ethanol $(30 \mathrm{~mL})$, and the reaction mixture was refluxed for $2.5 \mathrm{~h}$. The solution was concentrated under vacuum. The precipitate was filtered off, washed with methanol and dried under vacuum over anhydrous $\mathrm{CaCl}_{2}\left(1.30 \mathrm{~g}, 61 \%\right.$ yield). Conductance $\Lambda \mathrm{m}: 56 \Omega^{-1} \mathrm{~cm}^{2}$ $\mathrm{mol}^{-1}$. UV/vis (Nujol mul (nm)): $\lambda=260,272,325,520,724$ and 1150. IR (KBr): $v(\mathrm{H} 2 \mathrm{O})$ $3340(\mathrm{br}), v\left(\mathrm{~N}^{2} \mathrm{H}\right) 3260$ (br), v(C=S) $780(\mathrm{~s}), v(\mathrm{C}=\mathrm{N}) 1651(\mathrm{~m}), v(\mathrm{~N}-\mathrm{N}) 1123(\mathrm{w}), v(\mathrm{M}-\mathrm{N})$ $420, v(\mathrm{M}-\mathrm{O}) 500 \mathrm{~cm}^{-1} \cdot v_{\text {sym }}\left(\mathrm{OC}(\mathrm{O}) \mathrm{CH}_{3}\right) 1559(\mathrm{~m}), v_{\text {asym }}\left(\mathrm{OC}(\mathrm{O}) \mathrm{CH}_{3}\right) 1368 \mathrm{~cm}^{-1}(\mathrm{~m})$, $\left(\Delta v=191 \mathrm{~cm}^{-1}\right)$. Elemental analysis for $\mathrm{C}_{48} \mathrm{H}_{61} \mathrm{CrN}_{4} \mathrm{O}_{5} \mathrm{~S}_{2}$ (889.34): calcd. C 64.77, H 6.91, $\mathrm{N}$ 6.29, Cr 5.84; found C 64.60, H 6.92, N 6.25, Cr 5.80.

Synthesis of the metal complex (4)

Synthesis of $\mathrm{HLMnClH}_{2} \mathrm{O}$ complex (4). A solution of $\mathrm{MnCl}_{3}(0.476 \mathrm{~g}, 1.771 \mathrm{mmol})$ in methanol $(15 \mathrm{~mL})$ was added to a hot solution $\left(75^{\circ} \mathrm{C}\right)$ of $\mathrm{HL}(1)(1.294 \mathrm{~g}, 1.771 \mathrm{mmol})$ in ethanol $(18 \mathrm{~mL})$, the reaction mixture was refluxed for $4 \mathrm{~h}$. The precipitate was filtered off, washed with methanol and dried under vacuum over anhydrous $\mathrm{CaCl}_{2}(1.37 \mathrm{~g}, 80 \%$ yield). Conductance $\Lambda \mathrm{m}: 12 \Omega^{-1} \mathrm{~cm}^{2} \mathrm{~mol}^{-1}$. UV/vis (Nujol mul (nm)): $\lambda=260,280,320,450,700$, 1150. IR (KBr): $v\left(\mathrm{H}_{2} \mathrm{O}\right) 3380(\mathrm{br}), v\left(\mathrm{~N}^{2} \mathrm{H}\right) 3260(\mathrm{br}), v(\mathrm{C}=\mathrm{S}) 785(\mathrm{~s}), v(\mathrm{C}=\mathrm{N}) 1680(\mathrm{~s}), v(\mathrm{~N}-$ N) $1146(\mathrm{~s}), v(\mathrm{M}-\mathrm{N}) 440, v(\mathrm{M}-\mathrm{O}) 500 \mathrm{~cm}^{-1}$. Elemental analysis for $\mathrm{C}_{46} \mathrm{H}_{58} \mathrm{ClMnN}_{4} \mathrm{O}_{3} \mathrm{~S}_{2}$ (868.30): calcd. C 63.54, H 6.72, N 6.44, Mn 6.32; found C 63.35, H 6.92, N 6.38, Mn 6.42. Synthesis of the metal complex (5)

Synthesis of $\mathrm{HLMnNO}_{3} \mathrm{H}_{2} \mathrm{O}$ complex (5). A solution of $\mathrm{MnNO}_{3} \cdot 6 \mathrm{H}_{2} \mathrm{O}(0.354 \mathrm{~g}, 1.578$ $\mathrm{mmol})$ in methanol $(8 \mathrm{~mL})$ was added to a hot solution $\left(75^{\circ} \mathrm{C}\right)$ of $\mathrm{HL}(1)(1.203 \mathrm{~g}, 1.578$ $\mathrm{mmol})$ in ethanol $(25 \mathrm{~mL})$, and the reaction mixture was refluxed for $2.5 \mathrm{~h}$. The solution was concentrated under vacuum. The precipitate was filtered off, washed with methanol and dried under vacuum over anhydrous $\mathrm{CaCl}_{2}\left(1.06 \mathrm{~g}, 71 \%\right.$ yield). Conductance $4 \mathrm{~m}: 69 \Omega^{-1} \mathrm{~cm}^{2}$ $\mathrm{mol}^{-1}$. UV/vis (Nujol mul (nm)): $\lambda=255,275,320,525,720$ and 1155. IR $(\mathrm{KBr}): v\left(\mathrm{H}_{2} \mathrm{O}\right)$ $3429(\mathrm{br}), v\left(\mathrm{~N}^{2} \mathrm{H}\right) 3272(\mathrm{br}), v(\mathrm{C}=\mathrm{S}) 782(\mathrm{w}), v(\mathrm{C}=\mathrm{N}) 1644(\mathrm{~m}), v(\mathrm{~N}-\mathrm{N}) 1122(\mathrm{w}), v(\mathrm{M}-\mathrm{N})$ 
425, v(M-O) $490 \mathrm{~cm}^{-1}$. Elemental analysis for $\mathrm{C}_{46} \mathrm{H}_{58} \mathrm{MnN}_{5} \mathrm{O}_{6} \mathrm{~S}_{2}$ (895.32): calcd. C 61.66, $\mathrm{H}$ 6.52, N 7.82, Mn 6.13; found C 61.58, H 6.42, N 7.74, Cr 6.12.

Synthesis of the metal complex (6)

Synthesis of $\mathrm{HLMnOAcH}_{2} \mathrm{O}$ complex (6). A solution of $\mathrm{Mn}(\mathrm{OAc})_{3}(0.593 \mathrm{~g}, 1.953 \mathrm{mmol})$ in methanol $(10 \mathrm{~mL})$ was added to a hot solution $\left(75^{\circ} \mathrm{C}\right)$ of $\mathrm{HL}(1)(1.427 \mathrm{~g}, 1.953 \mathrm{mmol})$ in ethanol $(20 \mathrm{~mL})$, and the reaction mixture was refluxed for $4 \mathrm{~h}$. The precipitate was filtered off, washed with methanol and dried under vacuum over anhydrous $\mathrm{CaCl}_{2}(1.54 \mathrm{~g}, 81 \%$ yield). Conductance $\Lambda \mathrm{m}: 9 \Omega^{-1} \mathrm{~cm}^{2} \mathrm{~mol}^{-1}$. UV/vis (Nujol mul (nm)): $\lambda=255,280,330,451$, 680 and 1140. IR $(\mathrm{KBr}): v\left(\mathrm{H}_{2} \mathrm{O}\right) 3311(\mathrm{br}), v\left(\mathrm{~N}^{2} \mathrm{H}\right) 3260(\mathrm{br}), v(\mathrm{C}=\mathrm{S}) 784(\mathrm{~s}), v(\mathrm{C}=\mathrm{N}) 1657$ $(\mathrm{s}), v(\mathrm{~N}-\mathrm{N}) 1123(\mathrm{~m}), v(\mathrm{M}-\mathrm{N}) \quad 470, v(\mathrm{M}-\mathrm{O}) 510 \mathrm{~cm}^{-1}, v_{\mathrm{sym}}\left(\mathrm{OC}(\mathrm{O}) \mathrm{CH}_{3}\right) 1549(\mathrm{~m})$, $v_{\text {asym }}\left(\mathrm{OC}(\mathrm{O}) \mathrm{CH}_{3}\right) 1366 \mathrm{~cm}^{-1}(\mathrm{~m}),\left(\Delta v=190 \mathrm{~cm}^{-1}\right)$. Elemental analysis for $\mathrm{C}_{48} \mathrm{H}_{61} \mathrm{MnN}_{4} \mathrm{O}_{5} \mathrm{~S}_{2}$ (892.34): calcd. C 64.55, H 6.88, N 6.27, Mn 6.15; found C 64.42, H 6.89, N 6.04, Mn 6.12.

Synthesis of the metal complex (7)

Synthesis of $\mathrm{HLFeClH}_{2} \mathrm{O}$ complex (7). A solution of $\mathrm{FeCl}_{3} \cdot 6 \mathrm{H}_{2} \mathrm{O}(0.465 \mathrm{~g}, 1.723 \mathrm{mmol})$ in methanol $(11 \mathrm{~mL})$ was added to a hot solution $\left(75^{\circ} \mathrm{C}\right)$ of $\mathrm{HL}(1)(1.259 \mathrm{~g}, 1.723 \mathrm{mmol})$ in ethanol $(28 \mathrm{~mL})$, the reaction mixture was refluxed for $5 \mathrm{~h}$. The precipitate was filtered off, washed with methanol and dried under vacuum over anhydrous $\mathrm{CaCl}_{2}(1.28 \mathrm{~g}, 77 \%$ yield). Conductance $1 \mathrm{~m}: 17 \Omega^{-1} \mathrm{~cm}^{2} \mathrm{~mol}^{-1}$. UV/vis (Nujol mul (nm)): $\lambda=260,331,467,652$ and 1061. IR (KBr): $v\left(\mathrm{H}_{2} \mathrm{O}\right) 3406(\mathrm{br}), v\left(\mathrm{~N}^{2} \mathrm{H}\right) 3286(\mathrm{br}), v(\mathrm{C}=\mathrm{S}) 780(\mathrm{~s}), v(\mathrm{C}=\mathrm{N}) 1651(\mathrm{~s}), v(\mathrm{~N}-$ N) $1145, v(\mathrm{M}-\mathrm{N}) 455, v(\mathrm{M}-\mathrm{O}) 520 \mathrm{~cm}^{-1}$. Elemental analysis for $\mathrm{C}_{46} \mathrm{H}_{58} \mathrm{ClFeN}_{4} \mathrm{O}_{2} \mathrm{~S}_{2}$ (869.29): calcd. C 63.48, H 6.72, N 6.44, Fe 6.42; found C 63.37, H 6.62, N 6.50, Ni 6.43.

Synthesis of the metal complex (8)

Synthesis of $\mathrm{HLFeNO}_{3} \mathrm{H}_{2} \mathrm{O}$ complex (8). A solution of $\mathrm{FeNO}_{3} \cdot 6 \mathrm{H}_{2} \mathrm{O}(0.378 \mathrm{~g}, 1.678 \mathrm{mmol})$ in methanol $(8 \mathrm{~mL})$ was added to a hot solution $\left(75^{\circ} \mathrm{C}\right)$ of $\mathrm{HL}(1)(1.280 \mathrm{~g}, 1.678 \mathrm{mmol})$ in ethanol $(25 \mathrm{~mL})$, and the reaction mixture was refluxed for $5 \mathrm{~h}$. The solution was concentrated under vacuum. The precipitate was filtered off, washed with methanol and dried under vacuum over anhydrous $\mathrm{CaCl}_{2}\left(1.06 \mathrm{~g}, 71 \%\right.$ yield). Conductance $\Lambda \mathrm{m}: 69 \Omega^{-1} \mathrm{~cm}^{2}$ $\mathrm{mol}^{-1}$. UV/vis (Nujol mul (nm)): $\lambda=255,275,320,525,720$ and 1155. IR $(\mathrm{KBr}): v\left(\mathrm{H}_{2} \mathrm{O}\right)$ $3429(\mathrm{br}), v\left(\mathrm{~N}^{2} \mathrm{H}\right) 3272(\mathrm{br}), v(\mathrm{C}=\mathrm{S}) 780(\mathrm{w}), v(\mathrm{C}=\mathrm{N}) 1644(\mathrm{~m}), v(\mathrm{~N}-\mathrm{N}) 1122(\mathrm{w}), v(\mathrm{M}-\mathrm{N})$ $425, v(\mathrm{M}-\mathrm{O}) 490 \mathrm{~cm}^{-1}$. Elemental analysis for $\mathrm{C}_{46} \mathrm{H}_{58} \mathrm{ClFeN}_{5} \mathrm{O}_{6} \mathrm{~S}_{2}$ (896.31): calcd. C 61.60, H 6.52, N 7.81, Fe 6.23; found C 62.48, H 6.68, N 7.78, Fe 6.22.

Synthesis of the metal complex (9)

Synthesis of $\mathrm{HLFeOAcH} \mathrm{O}_{2} \mathrm{O}$ complex (9). A solution of $\mathrm{Fe}(\mathrm{OAc})_{3} \cdot 4 \mathrm{H}_{2} \mathrm{O}(0.563 \mathrm{~g}, 1.847$ $\mathrm{mmol})$ in methanol $(12 \mathrm{~mL})$ was added to a hot solution $\left(75^{\circ} \mathrm{C}\right)$ of $\mathrm{HL}(1)(1.350 \mathrm{mg}, 1.847$ $\mathrm{mmol})$ in ethanol $(25 \mathrm{~mL})$, the reaction mixture was refluxed for $5 \mathrm{~h}$. The precipitate was filtered off, washed with methanol and dried under vacuum over anhydrous $\mathrm{CaCl}_{2}(1.35 \mathrm{~g}$, $75 \%$ yield). Conductance $\Lambda \mathrm{m}: 15 \Omega^{-1} \mathrm{~cm}^{2} \mathrm{~mol}^{-1}$. UV/vis (Nujol mul (nm)): $\lambda=265,280$, 340, 489, 636, 1051. IR (KBr): v( $\left.\mathrm{H}_{2} \mathrm{O}\right) 3419(\mathrm{br}), v\left(\mathrm{~N}^{2} \mathrm{H}\right) 3277(\mathrm{br}), v(\mathrm{C}=\mathrm{S}) 780(\mathrm{~s}), v(\mathrm{C}=\mathrm{N})$ $1641(\mathrm{~s}), v(\mathrm{~N}-\mathrm{N}) 1122(\mathrm{w}), v(\mathrm{M}-\mathrm{N}) 460, v(\mathrm{M}-\mathrm{O}) 525 \mathrm{~cm}^{-1} v_{\mathrm{sym}}\left(\mathrm{OC}(\mathrm{O}) \mathrm{CH}_{3}\right) 1561(\mathrm{~m})$, $v_{\text {asym }}\left(\mathrm{OC}(\mathrm{O}) \mathrm{CH}_{3}\right) 1370 \mathrm{~cm}^{-1}(\mathrm{~m})\left(\Delta v=192 \mathrm{~cm}^{-1}\right)$. Elemental analysis for $\mathrm{C}_{48} \mathrm{H}_{61} \mathrm{FeN}_{4} \mathrm{O}_{5} \mathrm{~S}_{2}$ (893.34): calcd. C 64.49, H 6.88, N 6.27, Fe 6.25; found C 64.25, H 7.01, N 6.19, Fe 6.22.

\section{Results and discussion}

Mass spectra

The FAB mass spectra of Cr (III), Mn (III) and Fe (III) Schiff base complexes have been recorded. The molecular ion $\left(\mathrm{M}^{+}\right)$peaks obtained from various complexes are as follows: (1) $\mathrm{m} / \mathrm{e}=762.97$ (Ligand), (2) $\mathrm{m} / \mathrm{e}=865.30$ (complex 1), (3) $\mathrm{m} / \mathrm{e}=892.32($ complex 2), (4) $\mathrm{m} / \mathrm{e}$ $=889.34($ complex 3$),(5) \mathrm{m} / \mathrm{e}=868.30($ complex 4$),(6) \mathrm{m} / \mathrm{e}=895.32($ complex 5), (7) $\mathrm{m} / \mathrm{e}$ $=892.34$ (complex 6), (8) $\mathrm{m} / \mathrm{e}=869.29($ complex 7), (9) $\mathrm{m} / \mathrm{e}=896.31$ (complex 8), (10) $\mathrm{m} / \mathrm{e}=893.34$ (complex 9 ). This data is in good agreement with the proposed molecular 
formula for these complexes. In addition to the peaks due to the molecular ion, the spectra exhibit peaks assignable to various fragments arising from the thermal cleavage of the complexes. The peak intensity gives an idea of the stability of the fragments.

\section{IR Spectra}

The IR spectra of all complexes showed that the ligand HL (1) behaves as a neutral tetradentate of the type ONNO. The IR spectra provide valuable information regarding the nature of functional group attached to the metal atom. The presence of a single medium band in the region 3250-3330 $\mathrm{cm}^{-1}$ in the complexes may be assigned to $\mathrm{N}-\mathrm{H}$ stretch [37]. It was noted that a pair of bands corresponding to ${ }_{\mathrm{v}}\left(\mathrm{NH}_{2}\right)$ at $3245 \mathrm{~cm}^{-}{ }^{1}$ and $3309 \mathrm{~cm}^{-1}$ are present in the spectra of the Thio-carbohydrazide. The value of ${ }_{\mathrm{v}}(\mathrm{C}=\mathrm{N})$ stretching vibration is found (1590-1660 $\mathrm{cm}^{-}{ }^{1}$ ). The bands present in the range 3020-3040 $\mathrm{cm}^{-1}$ may be assigned due to (C-H) stretching vibrations of benzil and naphthalene ring [38]. The $\mathrm{C}-\mathrm{N}$ stretch in the range $1000-1300 \mathrm{~cm}^{-}{ }^{1}$. The band at $3292-3438 \mathrm{~cm}^{-}{ }^{1}$ is due to the presence of OH group in the complexes. This band is also present in the spectra of all the complexes. The far infrared spectra show bands in the region $420-450 \mathrm{~cm}^{-}{ }^{1}$ corresponding to $(\mathrm{M}-\mathrm{N})$ vibrations [39]. The band near 770-810 $\mathrm{cm}^{-}{ }^{1}$ in thiocarbohydrazide may be assigned as being due to free $\mathrm{v}(\mathrm{C}=\mathrm{S})$. The presence of bands in all complexes in the region $420-450 \mathrm{~cm}^{-1}$ originates from the $(\mathrm{M}-\mathrm{N})$ azomethine vibrational modes and identifies coordination of azomethine nitrogen [40]. The bands present at $290-310 \mathrm{~cm}^{-}{ }^{1}$ may be assigned due to ${ }_{\mathrm{v}}(\mathrm{M}-\mathrm{Cl})$ vibrations $[41,42]$. Infrared spectra of nitrato complexes display threes $(\mathrm{N}-\mathrm{O})$ stretching bands at 1410 $1455 \mathrm{~cm}^{-1}\left(v_{5}\right), 1305-1315 \mathrm{~cm}^{-1}\left(v_{1}\right)$ and $1015-1030 \mathrm{~cm}^{-1}\left(v_{2}\right)$. The separation of two highest frequency bands $\left(v_{5}-v_{1}\right)$, suggest that both the nitrate groups are coordinate as unidentate manner [43].

The appearance of two characteristic bands in the ranges $1561-1559 \mathrm{~cm}^{-1}$ and $1370-1367$ $\mathrm{cm}^{-1}$ in the case of complexes was attributed to $v_{\text {asym }}\left(\mathrm{COO}^{-}\right)$and $v_{\text {sym }}\left(\mathrm{COO}^{-}\right)$, respectively, indicating the participation of the carboxylate oxygen in the complexes formation. The mode of coordination of carboxylate group has often been deduced from the magnitude of the observed separation between the $v_{\text {asym }}\left(\mathrm{COO}^{-}\right)$and $v_{\text {sym }}\left(\mathrm{COO}^{-}\right)$. The separation value, $\Delta v\left(\mathrm{COO}^{-}\right)$, between $v_{\text {asym }}\left(\mathrm{COO}^{-}\right)$and $v_{\text {sym }}\left(\mathrm{COO}^{-}\right)$, in these complexes were more than 190 $\mathrm{cm}^{-1}\left(191-193 \mathrm{~cm}^{-1}\right)$ suggesting the coordination of carboxylate group in a monodentate fashion [44].

\section{${ }^{1} H$ NMR}

The ${ }^{1} \mathrm{H}$ NMR spectra of the ligand exhibits at $13.1 \mathrm{ppm}$ due to the $-\mathrm{NH}$ [45]. The multiplets in the region 7.04-7.86 ppm may be assigned to aromatic proton [46,47]. The ${ }^{1} \mathrm{H}$ NMR spectra of Schiff base ligand (HL) was recorded in $\mathrm{d}_{6}$-dimethylsulfoxide (DMFO- $\mathrm{d}_{6}$ ) solution using $\mathrm{Me}_{4} \mathrm{Si}$ (TMS) as internal standard.

\section{Magnetic measurements and electronic spectral studies}

The electronic spectra of $\mathrm{Cr}$ (III) complexes showed absorption band in the region 89509310, 13150-13520, 17550-18450 and 27380-27780 $\mathrm{cm}^{-1}$ attributed to ${ }^{4} \mathrm{~B}_{1 \mathrm{~g}} \rightarrow{ }^{4} \mathrm{E}_{1 \mathrm{~g}}$, ${ }^{4} \mathrm{~B}_{1 \mathrm{~g}} \rightarrow{ }^{4} \mathrm{~B}_{2 \mathrm{~g}},{ }^{4} \mathrm{~B}_{1 \mathrm{~g}} \rightarrow{ }^{4} \mathrm{~A}_{2 \mathrm{~g}}$ and ${ }^{4} \mathrm{~B}_{1 \mathrm{~g}} \rightarrow{ }^{4} \mathrm{E}_{\mathrm{g}}$ transition indication of distorted octahedral geometry [48]. The magnetic moment value for this complex was found to be 3.68-4.93 B.M.

The absorption spectral bands of manganese (III) complexes showed three spin allowed transitions: ${ }^{5} \mathrm{~B}_{1 \mathrm{~g}} \rightarrow{ }^{5} \mathrm{~A}_{1 \mathrm{gg}},{ }^{5} \mathrm{~B}_{1 \mathrm{~g}} \rightarrow{ }^{5} \mathrm{~B}_{2 \mathrm{~g}},{ }^{5} \mathrm{~B}_{1 \mathrm{~g}} \rightarrow{ }^{5} \mathrm{E}_{\mathrm{g}}$ appearing in the ranges $12250-12550,16150$ 18860 and $35450-35720 \mathrm{~cm}^{-1}$, respectively consistent with a typical $\mathrm{Mn}$ (III) in an octahedral environment [49]. The magnetic moment values for these complexes were found in the range 4.92-5.74 B.M expected for octahedral nickel complexes.

The electronic spectra of the iron (III) complexes gave two bands at 9850-9980, and 27650$27760 \mathrm{~cm}^{-1}$, which could be assigned to the transitions ${ }^{6} \mathrm{~A}_{1 \mathrm{~g}} \rightarrow{ }^{4} \mathrm{~T}_{1 \mathrm{~g}}$ and ${ }^{6} \mathrm{~A}_{1 \mathrm{~g}} \rightarrow{ }^{4} \mathrm{~T}_{2 \mathrm{~g}}$, 
respectively, suggesting an octahedral geometry around Fe (III) ion [50]. The complexes 5 and 6 show magnetic moment values in the range 5.20-5.45 B.M., which is smaller than the calculated value for two $\mathrm{Fe}$ (III) ions in octahedral geometries and this may be due to antiferromagnetism between the two ion-centers.

\section{Conclusion}

The analytical data showed the presence of one metal ion per ligand molecule and suggested a mononuclear structure for the complexes $\left[\mathrm{HLMXH}_{2} \mathrm{O}\right]$. The electronic spectral data is in the favour of a octahedral geometry of the complexes.

\section{Acknowledgement}

We wish to express our cordial thanks to proff. A.K. Singh, Deptt. of applied chemistry Division, IIT Roorkee for fruitful discussion and suggestion for performing this research work.

\section{References}

1. Crowley, J.D., Traynor, D.A., Watherburn, D.C., Met. Ions. Biol. Syst. 2000, 37, 37.

2. Busch, D.H., Science. 1971, 171, 241.

3. Campbell, K.A., Yikilmaz, E., Grant, C.V., Gregor, W., Miller, A.F., Britt, R.D., J. Am. Chem. Soc. 1999, 121, 4714.

4. More, P.G., Bhalvankar, R.B., Pattar, S.C., J. Indian Chem. Soc. 2001, 78, 474.

5. Baseer, M.A., Jadhav, V.D., Phule, R.M., Archana, Y.V., Vibhute, Y.B., Orient. J. Chem. 2000, 16, 553.

6. Pandeya, S.N., Sriram, D., Nath, G., Clercq, E.D., Il Farmaco. 1999, 54, 624.

7. Singh, W.M., Dash, B.C., Pesticides, 1988, 22, 33.

8. Singh, D.P., Kumar, K., Sharma, C., Eur. J. Med. Chem. 2009, 44. 3299..

9. Kumar, G., kumar, D., Devi, S., Johari, R., Singh, C.P., Eur. J. Med. Chem. 2010, 45, 3056.

10. Kulkarni, A., Patil, S.A., Badami, P.S., Eur. J. Med. Chem. 2009, 44, 2904.

11. Bagihalli, G.B., Avaji, P.G., Patil, S.A., Badami, P.S., Eur. J. Med. Chem. 2008, 43, 2639.

12. Singh, K., Bharwa, M.S., Tyagi, P., Eur. J. Med. Chem. 2007, 42, 394.

13. Ramesh, R., Maheswaran, S., J. Inorg. Biochem. 2003, 96, 457.

14. Vanco, J., Marek, J., Travnicek, Z., Racanska, E., Muselik, J., Svajlenova, O., J. Inorg. Biochem. 2008, 102, 595.

15. Silveira, V.C., Luz, J.S., Oliveira, C.C., Graziani, I., Ciriolo, M.R., Ferreira, A.M.C., J. Inorg. Biochem. 2008, 102, 1090.

16. Galal, S.A., Hegab, K.H., Kassab, A.S., Rodriguez, M.L., Kervin, S.M., El-Khamry, A.M.A., El-Diwani, H.I., Eur. J. Med. Chem. 2009, 44, 1500.

17. Zhong, X., Yi, J., Sun, J., Wei, H.-L., Liu, W.-S., Yu, K.-B., Eur. J. Med. Chem. 2006, 41, 1090.

18. Chaviara, A.T., Cox, P.J., Repana, K.H., Papi, R.M., Papazisis, K.T., Zambouli, D., Kortsaris, A.H., Kyriakidis, D.A., Bolos, C.A., J. Inorg. Biochem. 2004, 98, 1271.

19. Illan-Cabeza, N.A., Hueso-Urena, F., Moreno-Carretero, M.N., Martinez-Martos, J.M., Ramirez-Exposito, M.J., J. Inorg. Biochem. 2008, 102, 647.

20. Desai, S.B., Desai, P.B., Desai, K.R., Heterocycl. Commun. 2001, 7, 83.

21. Pathak, P., Jolly, V.S., Sharma, K.P., Orient. J. Chem. 2000, 16, 161.

22. Samadhiya, S., Halve, A., Orient. J. Chem. 2001, 17, 119.

23. Allah, S., Abid, A.M., Phosphorus, Sulfur Silicon Relat. Elem. 2001, 170, 75. 
24. Yoon, T.P., Jacobsen, E.N., Science, 2003, 299, 1691.

25. Yamada, T., Ikeno, T., Ohtsuka, Y., Kezuka, S., Sato, M., Iwakura, I., Sci. Technol. Adv. Mater. 2006, 7, 184.

26. Rayati, S., Torabi, N., Ghaemi, A., Mohebbi, S., Wojtczak, A., Kozakiewicz, A., Inorg. Chim. Acta, 2008, 361, 1239.

27. Mirkhani, V., Moghadam, M., Tangestaninejad, S., Mohammadpoor-Baltork, I., Shams, E., Rasouli, N., Appl. Catal. A, 2008, 334, 106.

28. Mirkhani, V., Moghadam, M., Tangestaninejad, S., Mohammadpoor-Baltork, I., Rasouli, N., Catal. Commun. 2008, 9, 219.

29. Chen Y., Ruppel, J.V., Zhang X.P., J. Am. Chem. Soc. 2007, 129, 12074.

30. Kurnoskin, A.V., Polymer. 1993, 34, 1060.

31. Bagihalli, G.B., Avaji, P.G., Patil, S.A., Badami, P.S., Eur. J. Med. Chem. 2008, 43, 2639.

32. Scozzafava, A., Supuran, C.T., J. Med. Chem. 2000, 43, 3677.

33. Rice, S.A., Givskov, M., Steinberg, P., Kjelleberg, S., J. Mol. Microbiol. Biotechnol. 1999, 1, 23.

34. Casiraghi, G., Casnati, G., Puglia, G., Sartori, G., Terenghi, G., J. Chem. Soc., Perkin Trans. 1980, 1, 1862.

35. Cozzi, P.G., Chem. Soc. Rev. 2004, 33, 410.

36. Kowalczyk, R.., Kwiatkowski, P., Skarzewski, J., Jurczak, J., J. Org. Chem. 2009, 74, 753.

37. Shakir, M., Nasman, O.S.M., Varkey, S.P., Polyhedron. 1996, 15, 309.

38. Singh, D.P., Kumar, R., Malik, V., Tyagi, P., Transition Met. Chem. 2007, 32, 1051.

39. S. Chandra, R. Kumar, Transition Met. Chem. 29 (2004) 269.

40. Rana, V.B., Singh, D.P., Singh, P., Teotia, M.P., Transition Met.Chem. 1982, 7, 174.

41. Shakir, M., Islam, K.S., Mohamed, A.K., Jahn, N., Transition Met. Chem. 1997, 22, 189.

42. Khan, T.A., Hasan, S.S., Varkey, S.P., Rather, M.A., Jahan, N., Shakir, M., Transition Met. Chem. 1997, 22, 4.

43. Chandra, S., Gupta, L.K., Spectrochim. Acta A, 2004, 60, 2767.

44. Boghaei, D.M., Gharagozlou, M., Spectrochem. Acta, 2007 67A, 944.

45. Gunthkal, M.S., Goudal, T.R., Patil, S.A., Oriental J. Chem. 2000, 16, 151.

46. Shakir, M., Chingsubam, P., Chishti, H.T.N., Azim, Y., Begum, N., Indian J. Chem. 2004, 43A, 556.

47. Niasari, M.S., Bazarganipour, M., Ganjali, M.R., Norouzi, P., Transition Met. Chem. 2007, $32,9$.

48. Wood, J.S., Prog. Inorg. Chem. 1972, 16, 227.

49. Singh, D.P., Rana, V.B., Polyhedron, 1995, 14, 2901.

50. A.B.P. Lever, Inorganic Electronic Spectroscopy, Elsevier, Amsterdam, 1984. 


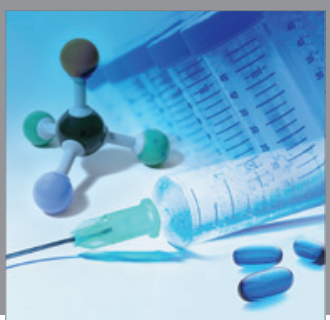

International Journal of

Medicinal Chemistry

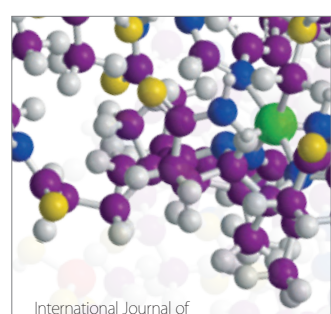

Carbohydrate Chemistry

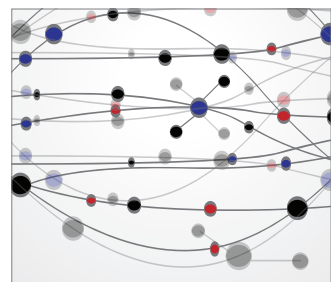

The Scientific World Journal
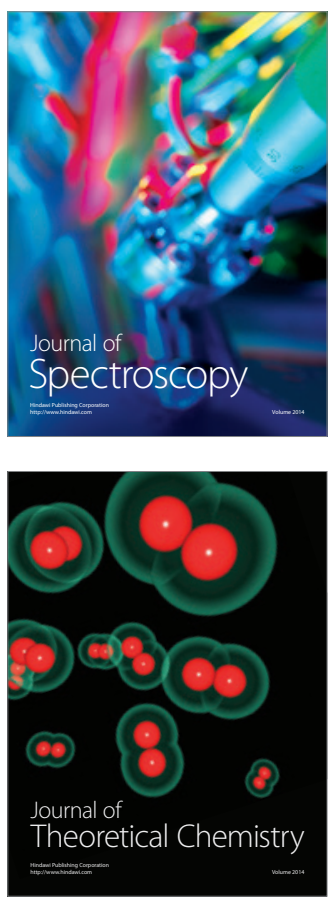
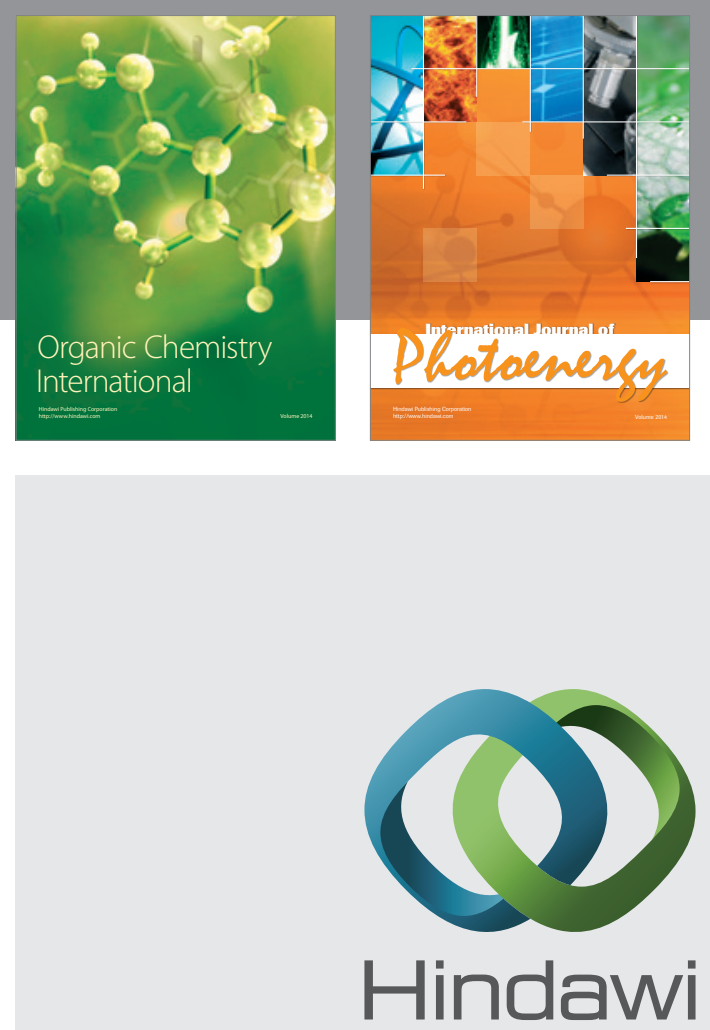

Submit your manuscripts at

http://www.hindawi.com
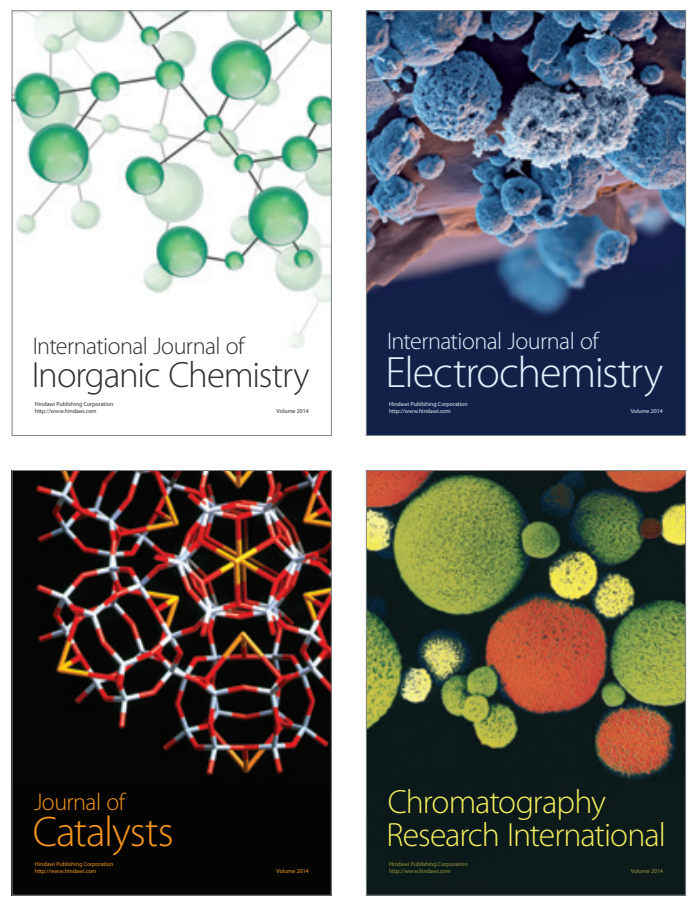
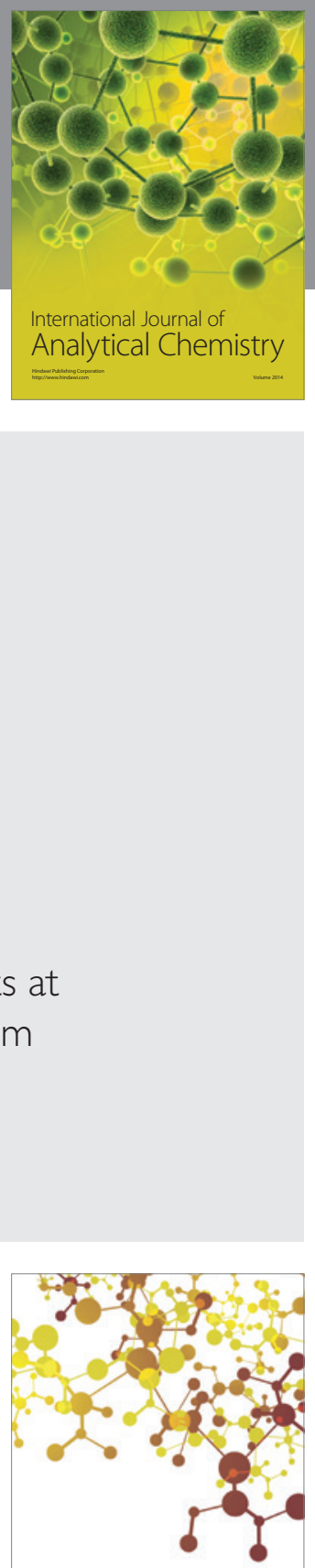

Journal of

Applied Chemistry
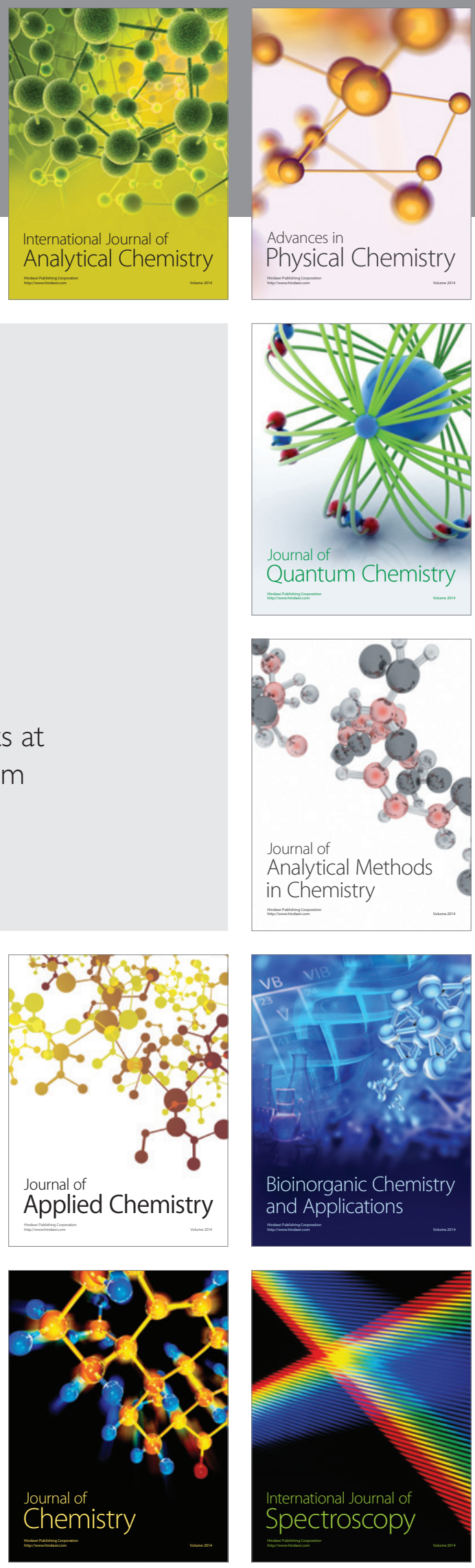